\title{
Keberlanjutan dan Dampak Jangka Panjang Operasi Perikanan Intensif di Tempat Pemijahan Ikan Baronang (Siganus canalicullat) di Pulau Papagaran-Taman Nasional Komodo
}

\author{
Sudaryanto ${ }^{1)}$, Herdis Herdiansyah ${ }^{1 *}$ \\ ${ }^{1)}$ Sekolah Ilmu Lingkungan, Universitas Indonesia, Jl. Salemba 4 Jakarta Pusat 10430, \\ Indonesia. \\ *Email: herdis@ui.ac.id
}

\begin{abstract}
Papagaran is an island located within the Komodo National Park area inhabited by more than 280 fisherman families. The main livelihood is the Siganus canaliculatus fishery in two ways of using tubal toxic materials, and benefits from the presence of group spawning sites near the coastal use zone. The fishermen observed a downward trend in the number of fish catches. This study aims to find the causes of the decline in the number of fish catches in the sea waters of Papagaran Island, and also to determine policy choices to realize conservation of spawned fish spawning areas. The research approach uses mixed quantitative and qualitative research methods. Quantitative methods use survey methods for villagers related to fishing activities. A qualitative approach is carried out to find out the history and possible causes of the decline in the number of fish catches based on observations and in-depth interviews. The conservation policy option needed in an effort to improve the condition of fish catches in the Papagaran area is done by counting. The results showed that fish were caught before laying eggs. The results of the AHP calculation obtained the results of conservation efforts of beron fish spawning were carried out by considering aspects of sustainability (67.16\%), socio-cultural (26.54\%), and economy (6.29\%). The results of the AHP calculation for alternative choices are consecutive formation (64.64\%), fishing time management $(25.54 \%)$ and replacement of fishing methods $(9.82 \%)$.
\end{abstract}

Keywords: intensive fisheries,spawning,sustainable fisheries,Baronang fish (Siganus canalicullatus)

\section{PENDAHULUAN}

Papagaran adalah sebuah pulau kecil yang terletak di dalam kawasan Taman Nasional Komodo, dan sebagai zona pemanfaatan tradisional sesuai dengan rencana pengelolaan 25 tahun yang diprakarsai oleh Pemerintah Republik Indonesia melalui Balai Taman Nasional Komodo (BTNK). Terdapat lebih dari 280 kepala keluarga nelayan yang menggantungkan hidupnya dari sumber daya pesisir di sekeliling pulau kecil tersebut.
Saat air laut surut, banyak keluarga nelayan yang mengumpulkan teripang melalui aktivitas pemungutan di terumbu karang. Ketika harga teripang kering meningkat, kerusakan karang dari pengumpulan terumbu karang sulit dihindari. Proses pengumpulan teripang yang tidak terkendali dan cenderung berlebih adalah salah satu dari bentuk ancaman langsung bagi kerusakan ekosistem karang (Burke et al., 2008; Mustofa, 2010). Nelayan dari desa sebagian besar memiliki jaring penggerak bergerak untuk menangkap 
spesies pelagis kecil, menggunakan lampu sebagai alat pengumpul dan belum adanya pengembangan ke arah penggunaan FAD (fish aggregating device) yang merupakan solusi untuk meningkatkan efektif dan efisiensi dari suatu operasi penangkapan (Jayanto et al., 2016).

Mangrove atau bakau merupakan ekosistem campuran antara ikan laut, ikan payau dan ikan air tawar. Penyebarannya tergantung pada karakteristik geografis, biologis, ekologis, dan fisikokimia air. Mangrove telah diketahui sebagai lokasi berkembang biak dan pertumbuhan benih ikan dan udang. Perkembangan tahap awal dan tahap muda ikan di lingkungan mangrove dapat menjadi indikator siklus terjaminnya reproduksi dan perjaminnya stok ikan dewasa. Selain itu, juga dapat membantu untuk memprediksi tempat ikan bertelur udang dan ikan, masa panen, dan potensinya. Hal ini bermanfaat untuk mengurangi eksploitasi sumber daya ikan yang berlebihan, atau sebaliknya dapat mengetahui penyebab rendahnya eksploitasi (Krishnamurthy \& Jeyaseelan, 1981). Hutan bakau terletak di bagian timur Pulau Papagaran. Selain hutan bakau, terdapat juga padang lamun dan terumbu karang.

Padang lamun merupakan ekosistem yang penting di daerah pesisir dan sublitoral karena dapat menjadi tempat hidup beberapa ikan dan hewan laut lainnya. Oleh sebab itu, wilayah Papagaran dapat menjadi tempat yang baik untuk perkembangbiakan ikan. Adanya terumbu karang di sekitar Pulau Papagaran memberi nilai tambah sebagai area perkembangbiakan ikan beronang (Hutomo \& Martosewojo, 1977).

Terdapat terumbu karang di sekitar lamun di Pulau Papagaran. Ini adalah tempat yang cocok untuk lahan pembibitan ikan baronang (Siganus) dan juga berbagai jenis ikan lainnya yang memanfaatkan ekosistem terumbu karang sebagai daerah asuhan (nurseryground) (Frisch, 2007). Selain itu, ekosistem ini dapat berfungsi sebagai pemeliharaan proses-proses ekologis dan system penyangga kehidupan di wilayah pesisir dan lautan (Restu, 2011). Dari segi social budaya, ekosistem ini memberikan manfaat langsung dan tidak langsung bagi penduduk yang hidup di wilayah pesisir (Burke et al., 2008; Sembiringet al., 2012)

Kawasan pantai Pulau Papagaran sebagian besar datar dan dangkal. Pada daerah seperti ini biasanya terbentuk perairan terisolasi seperti laguna yang menjadi menjadi habitat yang baik bagi rumput laut. Selain rumput laut, di tempat ini juga banyak terdapat copepoda dan hewan-hewan kecil lainnya. Oleh sebab itu, wilayah ini menjadi tempat yang ideal untuk kehidupan ikan karang termasuk ikan baronang.

Penangkapan ikan baronang secara tradisional di Papagaran dilakukan pada bulan Mei, diawali dengan upacara tradisional yang dipimpin oleh kepala desa. Semua keluarga akan pergi menangkap ikan dengan menggunakan racun alami (tuba). Meskipun penangkapan ikan dilakukan secara tradisional, namun pada awal tahun 2000-an diketahui terjadi penurunan populasi ikan tersebut. Diperkirakan penyebabnya adalah 'kamande' (tuba) yang dipakai, dan perangkap ikan (sero) di daerah pemijahan ikan beronang. Menghadapi masalah ini masyarakat telah melakukan beberapa sikap positif, yaitu : (1) masyarakat berinisiatif untuk mengetahui penyebab turunnya populasi ikan; (2) masyarakat mendapat pelajaran untuk tidak melanjutkan cara-cara tersebut; (3) kesempatan untuk mencari solusi bersama-sama dengan warga desa. 
Penelitian tentang ikan beronang berduri (Siganus spinus) di perairan Okinawa menemukan bahwa indeks Gonadosomatic tinggi selama bulan Mei hingga Juli, dan oosit bermuatan kuning telur diamati di ovarium dari Maret hingga Juli. Beberapa ovarium yang dikumpulkan selama bulan Juni dan Juli mengandung oosit pada tahap pematangan atau folikel siap ovulasi. Hasil ini menunjukkan bahwa ikan beronang berduri menjalani vitellogenesis aktif dan pemijahan dari Mei hingga Juli. Selama musim reproduksi (Mei hingga Juli), pengumpulan ikan sesuai dengan fase bulan, menunjukkan bahwa GSI (Indeks Gonad Somatik) yang tinggi terjadi sekitar waktu bulan baru. Pengembangan siklus oosit dengan puncak sekitar waktu fase bulan yang sama juga diamati, menunjukkan bahwa, di perairan Okinawa, spesies ini pematangan gonadnya mengikuti siklus dan muncul tiga kali (Harahapet al., 2001).

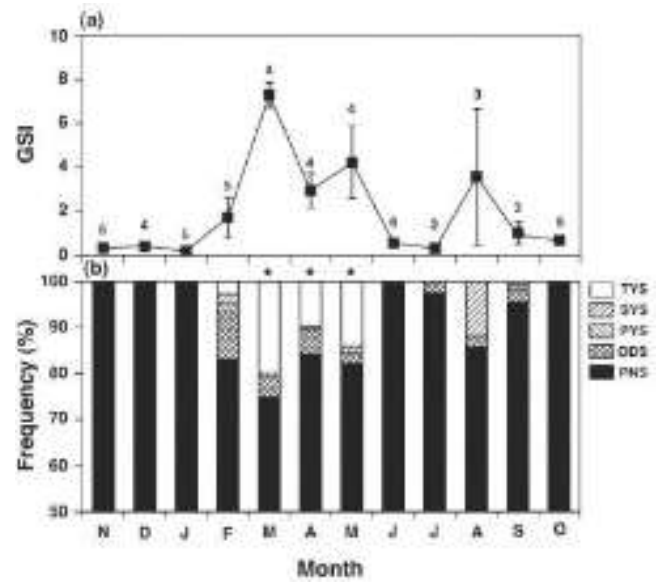

Gambar 1.

Perubahan bulanan pada Indeks Gonad Somatik (GSI) (a) dan komposisi oosit pada ikan betina (b)(Sumber: Hoque $e t$ al., 1998)

Perubahan tahunan dalam perkembangan oosit di ovarium dan serum vitellogenin, prekursor kuning telur, diselidiki pada ikan beronang,
Siganus canaliculatus, di Okinawa, Jepang Selatan. Perkembangan oosit secara histologis dibagi menjadi delapan tahap; kromatin-nukleolus, perinukleolus, tetesan minyak, kuning telur utama, kuning telur sekunder, kuning tersier, nukleus migrasi dan stadium maturasi. Oosit yang mengandung kuning telur pertama kali muncul pada bulan Maret. Dari April hingga Juni, komposisi tahap oosit dicirikan oleh persentase oosit yang tinggi yang melampaui tahap kuning telur primer dan berkorelasi dengan peningkatan indeks gonad-somatik $(G S I)$. Folikel pasca ovulasi dapat diamati di ovarium pada bulan Mei. Nilai GSI secara bertahap menurun setelah Juni dan dipertahankan pada level rendah dari Oktober hingga Februari. Selama bulan-bulan ini, indung telur ditempati oleh oosit yang belum matang pada tahap kromatin dan perinukleolus. Vitellogenin, yang diukur secara imunologis dengan antiserum antellum beronang, berubah sesuai dengan fluktuasi bulanan GSI serta perkembangan oosit yang mengandung kuning telur. Hasil ini menunjukkan bahwa S. canaliculatus memulai vitellogenesis pada bulan Maret dan memunculkan beberapa kali dalam tiga bulan berikutnya di Okinawa (Hoque et al., 1998).

Perairan pantai Mandapam memiliki potensi budidaya yang tinggi untuk S. Canaliculatus, karena merupakan daerah euryhalin, yaitu daerah yang memiliki salinitas berkisar antara 17 ppt hingga 37,0 ppt. Ikan-ikan muda berlimpah di daerah terumbu karang dan rumput laut di dekat Mandapam. Jumlah ikan $S$. canaliculatus muda yang melimpah terjadi selama bulan Februari hingga Mei di Teluk Mannar. Dilaporkan bahwa ikan dapat mencapai ukuran panjang total $20 \mathrm{~cm}$, yang dapat dipasarkan 
dalam waktu pertumbuhan selama 6 bulan. Ikan beronang ini dibudidayakan di negara-negara Asia Tenggara. India memiliki potensi besar untuk budidaya ikan beronang (Jaikuma, 2012)

Hasil penelitian terkait Indeks yang menggambarkan perubahan gonad secara relative dari waktu ke waktu adalah IKG (Indeks Kematangan Gonad) dan indeks gonad (IG). Nilai IKG ikan baronang di wilayah perairan Arakan Kecamatan Tatapaan Kabupaten Minahasa Selatan berkisar antara 0,1506-2,1845 dengan panjang total $236,72-298,84 \mathrm{~mm}$, nilai rata-rata indeks gonad (IG) berkisar antara 5,1920-28, 4828 dan perbandingan jenis kelamin dari individu jantan dan betina tidak 1:1 sehingga dapat dikatakan bahwa spesies ini mengalami kesulitan dalam mencari pasangan kawin (Tuegehet al., 2012).

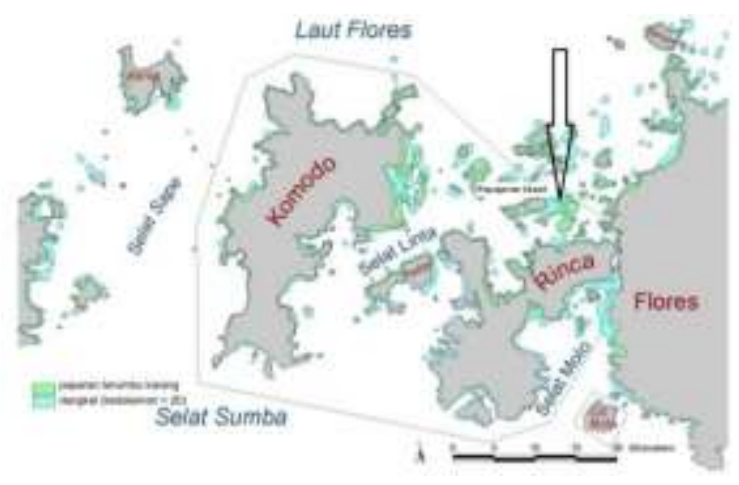

Gambar 2.

Terumbu karang di sekitar Pulau Papagaran di Taman Nasional Komodo

(Rencana Manajemen Taman Nasional Komodo)

\section{METODOLOGI}

Penelitian ini menggunakan metode survei untuk mengumpulkan data deskriptif kuantitatif. Data dari kegiatan penangkapan diolah dengan metode kualitatif yaitu dengan menggunakan diskusi kelompok terfokus di desa. Survei lapangan dilakukan pada malam penangkapan ikan dengan perangkap tradisional yang digabungkan dengan racun tuba. Penimbangan berat badan dan telur menggunakan keseimbangan digital. Panjang tubuh diukur dengan penggaris. Total telur potensial dihitung dengan sampling. Reproduksi tahunan dan siklus pemijahan yang berhubungan dengan bulan pada ikan beronang bergaris yang dikumpulkan dari Chuuk Lagoon, Negara Federasi Mikronesia, diperiksa secara histologis. Pengumpulan bulanan spesies ini mengungkapkan bahwa ovarium dengan oosit yang berkembang, mengandung kuning telur, dapat diamati dari bulan Februari hingga Mei dan pada bulan Agustus dan September. Pengambilan sampel ikan mingguan menunjukkan bahwa perkembangan indung telur dan pemijahan setelah kuartal pertama siklus bulan, diulangi selama musim reproduksi, menunjukkan bahwa spesies adalah memijah bulanan terbukti, dan melepaskan gamet sekitar waktu kuartal pertama siklus bulan (Park, 2006).

Selanjutnya penelitian ini menerapkan teknik stripping dari ikan dewasa. Telur bercampur dengan sperma dicampur dalam air laut dengan dilengkapi aerator. Telur yang dibuahi diinkubasi dilokasi. Telur menetas dalam 30 hingga 36 jam. Peneliti mengumpulkan beberapa telur dari pemijahan alami pada bulan Oktober dan menetas dalam waktu 27 jam di lokasi. Proses ini dilakukan di depan masyarakat desa untuk memberi pemahaman bagaimana terjadinya penurunan populasi di alam. Penduduk desa telah melihat bentuk larva dari dua teknik yaitu pembuahan telur dari pemijahan alami dan pembuahan buatan dengan teknik stripping. Hal ini telah memberi pelajaran tentang cara regenerasi dari ikan baronang, dan munculnya pemahaman yang dalam 
tentang mengapa hasil tangkapan menurun.

Selanjutnya untuk menentukan opsi kebijakan konservasi yang diperlukan dalam upaya memperbaiki kondisi tangkapan ikan di wilayah Papagaran dilakukan penghitungan dilakukan dengan menggunakan metode AHP (Analytical Hierarchy Process). Dalam penelitian ini, dibuat tiga level hirarki yakni tujuan, kriteria dan pilihan.

\section{HASIL DAN PEMBAHASAN}

\subsection{Hasil}

Populasi penduduk desa Papagaran sendiri adalah 1.074 orang dari 280 keluarga. Mereka mempunyai mata pencaharian utama $90 \%$ sebagai nelayan. Survei mata pencaharian masyarakat menunjukkan adanya matapencaharian sebagai pemasok air, toko kecil, pengumpul ikan, dan guru. Bagan apung adalah peralatan yang dominan untuk menangkap ikan pelagis kecil dan cumicumi. Teknik lain dioperasikan jaring apung, dan perangkap ikan. Pada saat air surut, mereka akan menangkap kerang abalone, teripang, dan lain-lain. Aktivitan nelayan yang populer di samping menangkap cumi-cumi di Papagaran adalah menangkap ikan baronang. Mereka menangkap ikan beronang sejak Mei hingga Desember menggunakan 'tuba/kamande'. Teknik lainnya adalah penangkapan dengan perangkap di lokasi pemijahan secara berkelompok dalam periode pemijahan (Agustus hingga Oktober). Operasi penangkapan ikan dengan perangkap dilakaukan selama 3 hari setiap bulan pada saat menjelang bulan baru. Teknik penangkapan ikan berobang, digambarkan pada Tabel 1 .

Tabel 1.Operasi Penangkapan Ikan di Desa Papagaran

\begin{tabular}{|c|c|c|c|c|c|c|c|c|c|c|c|c|c|}
\hline \multirow{2}{*}{ No } & \multirow{2}{*}{ Aktivitas } & \multicolumn{12}{|c|}{ Bulan ke- } \\
\hline & & 1 & 2 & 3 & 4 & 5 & 6 & 7 & 8 & 9 & 10 & 11 & 12 \\
\hline 1 & Bagan apung & & & & & & & & & & & & \\
\hline 2 & Memancing & & & & & & & & & & & & \\
\hline 3 & Abalone \& teripang & & & & & & & & & & & & \\
\hline 4 & $\begin{array}{l}\text { Pengangkapan beronang } \\
\text { dengan tuba }\end{array}$ & & & & & & & & & & & & \\
\hline 5 & $\begin{array}{l}\text { Penangkapan beronang } \\
\text { dengan sero di lokasi } \\
\text { pemijahan }\end{array}$ & & & & & & & & & & & & \\
\hline
\end{tabular}

Penangkapan ikan beronang berlangsung sangat dekat dengan pantai karena mereka biasanya berkeliling mencari makan dan berjemur di padang lamun yang hangat dan dangkal. Kegiatan menangkap dengan tuba, yang sudah berlangsung sejak lama secara tradisional disebut perikanan 'kamande'. Penduduk desa menjelaskan bahwa ikan mulai berkumpul untuk bertelur di dalam laguna yang biasanya terjadi saat air surut di lokasi yang sama di bulan Agustus. Ada sebanyak 17 perangkap ikan (sero) yang ada di sekitar desa
Papagaran untuk menangkap beronang selama musim bertelur ini. Rombongan ikan beronang biasanya bertelur di masa awal bulan (tanggal 2, 3, dan 4 menurut siklus bulan). Sistem pengarahan ikan bergerombol yang sudah matang gonad akan mengikuti aliran air surut dan diarahkan sedemikian rupa sehingga memasuki ujung sero. Dengan demikian seluruh populasi ikan siap memijah di area tersebut akan terperangkap.

Masa penangkapan ikan baronang ditutup melalui peraturan kepala desa di bulan Januari hingga Mei. Periode waktu 
ini dapat digunakan oleh ikan untuk tumbuh sampai ukurannya cukup besar dan menyebar di perairan sekitarnya. Sebagian besar penduduk desa Papagaran mengakui bahwa penangkapan ikan beronang yang semakin sulit sejak tahun 2001.
Diperkirakan oleh penduduk Papagaran bahwa telah terjadi perubahan jumlah ikan di laut. Hal ini terlihat dari jumlah tangkapan keseluruhan yang dibandingkan antara periode tangkapan tahun 1993 dan 2003 yang disajikan pada Tabel 2.

Tabel 2. Indikasi Penipisan Populasi Ikan Baronang

\begin{tabular}{|c|c|c|c|}
\hline No & Volume & 1993 & 2003 \\
\hline \multirow[t]{2}{*}{1} & $\begin{array}{l}\text { Volume penangkapan } \\
\text { menggunakan kamande }(100 \mathrm{~kg} \\
\text { ikan/kapal) }\end{array}$ & $10 \mathrm{kapal} / \mathrm{hari}$ & $3 \mathrm{kapal} / \mathrm{hari}$ \\
\hline & Frekuensi penggunaan kamande & 20 hari dalam 8 bulan & 10 hari dalam 6 bulan \\
\hline \multirow[t]{2}{*}{2} & $\begin{array}{l}\text { Volume penangkapan } \\
\text { menggunakan perangkap sero } \\
(100 \mathrm{~kg} \text { ikan/kapal) }\end{array}$ & $\begin{array}{l}2 \mathrm{kapal} / \mathrm{hari} / \text { perangkap } \\
\text { sero (total } 17 \text { unit } \\
\text { sero) }\end{array}$ & $\begin{array}{l}0,5 \mathrm{kapal} / \mathrm{hari} / \mathrm{perangkap} \\
\text { sero (total } 17 \text { unit sero) }\end{array}$ \\
\hline & $\begin{array}{l}\text { Frekuensi penangkapan } \\
\text { menggunakan perangkap sero }\end{array}$ & 3 hari dalam 3 bulan & 3 hari dalam 2 bulan \\
\hline
\end{tabular}

Data menunjukkan penurunan frekuensi penangkapan, periode bulan, dan volume tangkapan harian. Data tangkapan massal menunjukkan bahwa masa menangkap menurun dari 160 hari per tahun menjadi 60 hari per tahun. Ketika asumsi perahu dapat membawa $100 \mathrm{~kg}$ ikan/hari, dengan dalam 8 bulan pada tahun 1993, masyarakat dapat mengumpulkan total $190.600 \mathrm{~kg}$ ikan per tahun, sangat berkurang dibandingkan dengan 10 tahun kemudian dengan total tangkapan ikan sebanyak $23.100 \mathrm{~kg}$ per tahun.

Tabel 3. RasioJenis Kelamin

\begin{tabular}{lllll}
\multicolumn{1}{c}{ Parameter } & Bulan ke- & Jantan (\%) & Betina (\%) & Total(\%) \\
\hline Rasio jenis kelamin & 1 & 53 & 47 & 100 \\
& 2 & 35 & 65 & 100 \\
& 3 & 40 & 60 & 100 \\
Rata-rata & 43 & 57 & 100 \\
\hline
\end{tabular}

Rasio jenis kelamin pada pemijahan berkelompok terdiri dari $43 \%$ jantan dan $57 \%$ betina, menunjukkan bahwa betina lebih banyak daripada jantan. Ukuran jantan adalah rata-rata lebih kecil dibanding betina dalam panjang dan berat badan. Dengan
Pengurangan tangkapan ini diduga disebabkan juga oleh adanya pengaruh penangkapan ikan di area pemijahan massal di sekitar hamparan padang lamun. Penangkapan menggunakan alat sero yang dipasang secara permanen. Pada tahun 1993, hasil tangkapan induk ikan di area pemijahan dapat menghasilkan $30.600 \mathrm{~kg}$ per tahun, sedangkan pada tahun 2003 hanya menghasilkan $5.100 \mathrm{~kg}$ per tahun. Maengapa hal ini dapat terjadi akan didiskusikan menyangkut potensi pembuahan yang akan dibahas dibagian berikutnya. pemijahan, sperma dapat membuahi telur yang dilepaskan pada saat yang sama dengan sel telur, dan dalam jarak dekat dari satu induk dengan yang lain. Memijah dengan sistem ini terlihat sangat efektif. 
Tabel 4. Perhitungan Total Panjang, Berat Badan, Berat Gonad, dan Jumlah Telur Ikan Beronang pada Bulan Agustus Sampai Oktober 2002 oleh Nelayan Papagaran

\begin{tabular}{|c|c|c|c|c|c|}
\hline No & Parameter & Bulanke- & Jantan & Betina & Rata-rata \\
\hline \multirow[t]{3}{*}{1} & Panjang total $(\mathrm{cm})$ & 1 & 15.6 & 18.8 & 17.1 \\
\hline & & 2 & 16.4 & 19.1 & 18.1 \\
\hline & & 3 & 16.4 & 19.6 & \\
\hline \multirow[t]{3}{*}{2} & Berat badan (gr) & 1 & 47.7 & 101.0 & 72.7 \\
\hline & & 2 & 69.4 & 108.8 & 95.0 \\
\hline & & 3 & 62.1 & 105.9 & 84.0 \\
\hline \multirow[t]{3}{*}{3} & GSI (\%) & 1 & - & 24.3 & - \\
\hline & & 2 & - & 20.5 & - \\
\hline & & 3 & & 31.8 & - \\
\hline \multirow[t]{3}{*}{4} & Pelepasan telur (\%) & 1 & - & 0.0 & - \\
\hline & & 2 & - & 34.6 & - \\
\hline & & 3 & - & $>90$ & - \\
\hline \multirow[t]{3}{*}{5} & Jumlah telur (telur/betina) & 1 & - & 254,567 & - \\
\hline & & 2 & - & 246,196 & - \\
\hline & & 3 & - & 250,381 & 250,381 \\
\hline
\end{tabular}

Pada tabel 4 dapat dihitung estimasi potensi kehilangan telur yang subur. Potensi hilangnya telur karena ditangkap adalah 250.381 butir telur/ekor ikan betina. Induk betina akan melepaskan telur sejak hari kedua dari total $34 \%$ betina dan hari ketiga dari total $>90 \%$ betina. Selama ini para nelayan menangkap semua ikan dalam perangkap pada masa tersebut. Teknik penangkapan ini akan membuat sangat sedikit ikan yang tersisa untuk bertelur dalam periode tersebut dan pada tahuntahu selanjutnya. Pada saat itu, diprediksi populasi ikan beronang akan terus menipis.

Tabel 5.Potensi Kehilangan Telur

\begin{tabular}{lllll}
\hline Parameter & Bulan ke- & Sperma & Jumlah telur & Rata-rata \\
\hline Kehilangan telur (telur) & 1 & - & $884,812,394$ & - \\
& 2 & - & $4,850,894,573$ & - \\
& 3 & & $3,981,057,900$ & \\
Total & & & $\mathbf{9 , 7 1 6 , 7 6 4 , 8 6 7}$ & \\
\hline
\end{tabular}

Catatan:

Bulan ke- $\quad=\quad$ 1:Agustus; 2:September; 3: Oktober - $\quad=\quad$ tidak ada data spesifik

Teknik penangkapan ini akan mengnangkap habis semua induk yang akan bertelur di area pemijahan. Ketika kami menghitung total kerugian dari potensi pelepasan telur selama 3 bulan periode penelitian adalah 9.716.764.867 butir telur. Berapa banyak kita sudah kehilangan telur selama 10 tahun sebelumnya, sehingga ini adalah salah satu alasan mengapa hasil tangkapan ikan beronang terus mengalami penurunan dari tahun ke tahun.. Hal ini jika dibiarkan terjadi terus-menerus maka akan over fishing, yaitu kondisi jika upaya peningkatan penangkapan sudah tidak dapat lagi meningkatkan 
hasil tangkapan (Budiarto, 2015). Jika kondisi ini tidak segera dikelola dengan baik, dapat mengakibatkan perubahan ekosistem perairan dan kerusakan habitat (Tamarol, et al, 2012) Kondisi overfishing mengindikasikan bahwa perikanan tangkap di lokasi harus diantisipasi dengan melakukan perbaikan habitat ikan, konservasi hutan mangrove, peningkatan pemahaman dan kesadaran nelayan untuk menjaga keseimbangan ekosistem pantai (Nurhayati, 2013).

\subsection{Pembahasan}

Masyarakat

Papagaran menginginkan adanya peningkatan hasil tangkapan ikan baronang dan hasil yang bisa konsisten setiap waktu. Untuk memenuhi tujuan tersebut, salah satu langkah yang paling memungkinkan untuk dilakukan adalah menetapkan kebijakan konservasi. Tujuan dari konservasi ini antara lain untuk memastikan kesinambungan dari keanekaragaman hayati dan juga terkait dengan potensi pemanfaatan ikan untuk kepentingan di sekitarnya (Prianto, et al, 2014). Pada penelitian ini, upaya pemilihan bentuk konservasi ditentukan dengan menggunakan metode AHP (Analytical Hierarchy Process). Metode
AHP banyak digunakan dalam membantu menentukan keputusan yang diambil. Metode ini dikembangkan oleh Thomas L. Saaty dengan mengembangkan model hirarki ini menguraikan masalah pengambilan keputusan yang terdiri atas multi faktor (Saaty \& Hu, 1998). Hirarki dalam model AHP terbagi dalam beberapa level, yakni level pertama sebagai tujuan, level selanjutnya adalah kriteria, diikuti dengan subkriteria atau langsung pada level opsi kebijakan yang hendak diputuskan.

Pada penelitian ini, hirarki yang dibangun terdiri dari tiga level, yakni level pertama adalah tujuan, level kedua adalah kriteria dan level terakhir adalah alternatif. Tujuan dari penggunaan metode ini adalah untuk menetapkan konservasi pemijahan ikan baronang. Sedangkan kriteria yang ditetapkan agar konservasi berjalan tepat sasaran adalah upaya yang dilakukan dapat memenuhi kriteria ekonomi, keberlanjutan dan sosial budaya masyarakat di wilayah Papagaran.

Berikut model AHP untuk menetapkan konservasi ikan baronang di Papagaran:

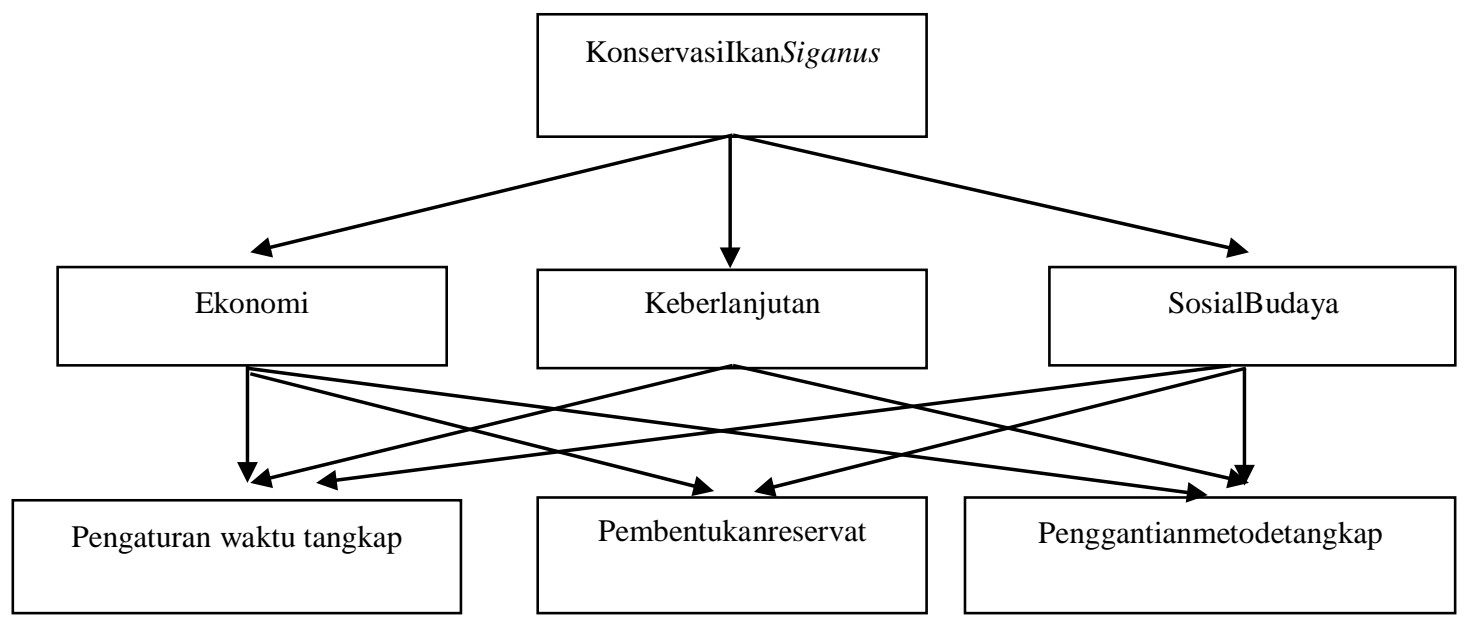

Gambar 3.

Model AHP untuk Penentuan Konservasi Ikan Siganus 
Langkah berikutnya adalah berpasangan menggunakan skala 1-9 membuat matriks perbandingan untuk menggambarkan tingkat berpasangan antar elemen pada kriteria kepentingan antar elemen (Saaty, 1998). dan alternatif untuk mengukur kontribusi Pada penelitian ini terdapat 4 matriks setiap elemen pada level di atasnya. perbandingan berpasangan yang Perhitungan pada perbandingan digambarkan pada tabel 6-9.

Tabel 6.Perbandingan Berpasangan antara Kriteria terhadap Tujuan

\begin{tabular}{llll}
\hline \multicolumn{1}{c}{ Konservasi Ikan } & \multicolumn{1}{c}{ Ekonomi } & Keberlanjutan & Sosial Budaya \\
\hline Ekonomi & 1 & 0,11 & 0,20 \\
Keberlanjutan & 9 & 1 & 3 \\
SosialBudaya & 5 & 0,33 & 1 \\
\hline Konservasi Ikan & Persentase & & \\
\hline Ekonomi & $6,29 \%$ & & \\
Keberlanjutan & $67,16 \%$ & & \\
SosialBudaya & $26,54 \%$ & & \\
Consistency Ratio & $2,80 \%$ & & \\
\hline
\end{tabular}

Tabel 6 menggambarkan bahwa kriteria keberlanjutan adalah kriteria utama dalam penentuan alternatif dalam mewujudkan konservasi di Papagaran. Urutan prioritas kriteria yang perlu dipertimbangkan adalah keberlanjutan $(67,16 \%)$ diikuti dengan kesesuaian dengan sosial budaya masyarakat $(26,54 \%)$ dan peritmbangan ekonomi merupakan kriteria terakhir untuk dipertimbangkan dengan porsi sebesar $6,29 \%$. Hasil perbandingan berpasangan ini valid berdasarkan nilai Consistency Ratio 2,80\%. Menurut Saaty (1998) menyebutkan bahwa metode AHP melibatkan penilaian yang beragam sehingga perlu mengukur konsistensi penilaian dengan menetapkan batas Consistency Ratio $\leq 10 \%$.

Tabel 7. Matriks Perbandingan Berpasangan antara Alternatif terhadap Kriteria Ekonomi

\begin{tabular}{llll}
\hline \multicolumn{1}{c}{ Ekonomi } & $\begin{array}{c}\text { Pengaturan waktu } \\
\text { tangkap }\end{array}$ & $\begin{array}{c}\text { Pembentukan } \\
\text { reservat }\end{array}$ & $\begin{array}{c}\text { Penggantian } \\
\text { metode tangkap }\end{array}$ \\
\hline Pengaturan waktu tangkap & 1 & 0,33 & 5 \\
Pembentukan reservat & 3 & 1 & 7 \\
$\begin{array}{l}\text { Penggantian metode } \\
\text { tangkap }\end{array}$ & 0,20 & 0,14 & 1 \\
\hline $\begin{array}{l}\text { Pilihan alternatif } \\
\text { Pengaturan waktu tangkap }\end{array}$ & $\begin{array}{l}\text { Persentase } \\
\text { Pembentukan reservat }\end{array}$ & $64,89 \%$ & \\
$\begin{array}{l}\text { Penggantian metode } \\
\text { tangkap }\end{array}$ & $7,19 \%$ & & \\
\hline Consistency Ratio & & & \\
\hline
\end{tabular}

Hasil analisis perbandingan pembentukan reservat merupakan opsi berpasangan antara alternatif dengan terbaik dengan angka 64,19\%, diikuti memperhatikan kriteria ekonomi pada oleh kebijakan tentang pengaturan waktu tabel 7 dan kriteria keberlanjutan pada penangkapan ikan sebesar 27,89\% dan tabel 8 menunjukkan bahwa pilihan terakhir adalah kebijakan untuk 
mengganti metode penangkapan dengan metode yang lebih ramah lingkungan (7,19\%0. Reservat adalah kawasan atau suaka yang dibuat khusus untuk melindungi kawanan ikan, sehingga bisa hidup dan berkembang biak (Prianto et al., 2014) Pembentukan reservat ini dipandang memenuhi kriteria ekonomi karena dapat meningkatkan potensi sumber daya ikan dan nilai ekonomisnya. Terhadap pertimbangan aspek keberlanjutan, pembentukan reservat ini meningkatkan daya tahan lingkungan perairan dan kelangsungan ikan yang ada di dalamnya.

Tabel 8. Matriks Perbandingan Berpasangan Antara Alternatif Terhadap Kriteria Keberlanjutan

\begin{tabular}{|c|c|c|c|}
\hline Keberlanjutan & $\begin{array}{c}\text { Pengaturan waktu } \\
\text { tangkap }\end{array}$ & $\begin{array}{c}\text { Pembentukan } \\
\text { reservat }\end{array}$ & $\begin{array}{c}\text { Penggantian } \\
\text { metode tangkap }\end{array}$ \\
\hline $\begin{array}{l}\text { Pengaturan waktu } \\
\text { tangkap }\end{array}$ & 1 & 0,33 & 3 \\
\hline $\begin{array}{l}\text { Pembentukan } \\
\text { reservat }\end{array}$ & 3 & 1 & 7 \\
\hline $\begin{array}{l}\text { Penggantian metode } \\
\text { tangkap }\end{array}$ & 0,33 & 0,14 & 1 \\
\hline Pilihan Alternatif & Persentase & & \\
\hline $\begin{array}{l}\text { Pengaturan waktu } \\
\text { tangkap }\end{array}$ & $24,26 \%$ & & \\
\hline $\begin{array}{l}\text { Pembentukan } \\
\text { reservat }\end{array}$ & $66,94 \%$ & & \\
\hline $\begin{array}{l}\text { Penggantian metode } \\
\text { tangkap }\end{array}$ & $8,79 \%$ & & \\
\hline Consistency Ratio & $0,07 \%$ & & \\
\hline \begin{tabular}{l}
\multicolumn{2}{c}{ Selanjutnya } \\
perbandingan ber \\
pilihan alternatif terl \\
budaya. Pada tabel \\
konservasi r di \\
kepentingannya t \\
konservasi terhadap 1
\end{tabular} & $\begin{array}{lr}\text { dilakukan } \\
\text { asanan } & \text { terhadap } \\
\text { ladap kriteria sosial } \\
9, \text { opsi } & \text { kebijakan } \\
\text { nilai } & \text { tingkat } \\
\text { erhadap } & \text { dampak } \\
\text { Condisi masyarakat }\end{array}$ & $\begin{array}{l}\text { lokal baik secara } \\
\text { lokal maupun } \\
\text { masyarakatnya. Unsu } \\
\text { berpengaruh nantiny } \\
\text { masyarakat untuk } \\
\text { yang }\end{array}$ & $\begin{array}{rr}\text { nilai-nilai } & \text { kearifan } \\
\text { kondisi } & \text { sosial } \\
\text { ur sosial budaya ini } \\
\text { a pada } \\
\text { menaati kepatuhan } \\
\\
\\
\text { diterapkanan }\end{array}$ \\
\hline Sosial Budaya & $\begin{array}{c}\text { Pengaturan waktu } \\
\text { tangkap }\end{array}$ & $\begin{array}{c}\text { Pembentukan } \\
\text { reservat }\end{array}$ & $\begin{array}{c}\text { Penggantian metode } \\
\text { tangkap }\end{array}$ \\
\hline $\begin{array}{l}\text { Pengaturan } \\
\text { tangkap }\end{array}$ & 1 & 0,33 & 3 \\
\hline Pembentukan reservat & 3 & 1 & 5 \\
\hline $\begin{array}{l}\text { Penggantian metode } \\
\text { tangkap }\end{array}$ & 0,33 & 0,20 & 1 \\
\hline Pilihan Alternatif & Persentase & & \\
\hline $\begin{array}{l}\text { Pengaturan } \\
\text { waktutangkap }\end{array}$ & $63,70 \%$ & & \\
\hline Pembentukan reservat & $25,83 \%$ & & \\
\hline $\begin{array}{ll}\text { Penggantian } & \text { metode } \\
\text { tangkap } & \end{array}$ & $10,47 \%$ & & \\
\hline Consistency Ratio & $3,70 \%$ & & \\
\hline
\end{tabular}


Hasil analisis antara elemen alternatif terhadap factor sosial budaya menunjukkan bahwa pengaturan waktu tangkap merupakan opsi kebijakan yang diprioritaskan $(63,70 \%)$ diikuti oleh pilihan untuk membentuk reservat $(25,83 \%)$ dan mengganti metode penangkapan ikan oleh masyarakat dengan hasil sebesar 10,47\%.

Pengaturan waktu tangkap dipandang sebagai upaya yang dapat diterima secara sosial budaya oleh masyarakat Papagaran. Untuk mendukung opsi ini, maka pengambil kebijakan perlu juga meningkatkan kesadaran masyarakat sehingga dapat juga meningkatkan derajat kepatuhannya. Tabel 10 menunjukkan urutan prioritas pemilihan alternatif untuk konservasi pemijahan ikan berdasarkan hasil analisis AHP.

Tabel 10. Hasil Analisis AHP

\begin{tabular}{|c|c|c|}
\hline Hasil AHP & Normal & Ideal \\
\hline Pengaturan waktu tangkap & $25,54 \%$ & $39,52 \%$ \\
\hline Pembentukan reservat & $64,64 \%$ & $100 \%$ \\
\hline $\begin{array}{l}\text { Penggantian metode } \\
\text { tangkap }\end{array}$ & $9,82 \%$ & $15,19 \%$ \\
\hline
\end{tabular}

Urutan pilihan yang dapat baronang, terutama saat air surut. Para diterapkan untuk menyelamatkan nelayan menempatkan sero perangkap perikanan ikan baronang adalah dengan ikan di laguna kecil yang biasanya pembentukan reservat $(64,64 \%)$, terbentuk saat air surut. Untuk memandu pengaturan waktu tangkap yang lebih lebih banyak gerombolan ikan ke dalam selektif $(25,54 \%)$ dan alternatif terakhir adalah mengubah metode penangkapan ikan $(9,82 \%)$.

Secara tradisional, masyarakat Papagaran sudah memiliki kearifan lokal ketika menangkap ikan baronang. Namun, kearifan lokal masih memiliki kelemahan, yaitu menangkap ikan masih menggunakan racun tuba. Kekurangan lainnya adalah bahwa orang menangkap ikan di tempat pemijahan massal selama periode pemijahan. Hal ini masih jauh dari yang diharapkan terkait dengan konsep suatu kearifan lokal dimana kesadaran masyarakat untuk mengatur kehidupannya menjadi lebih baik tidak sejalan dengan kondisi sumber daya yang terus mengalami penurunan (Sartini, 2004). Alat tangkap yang tidak ramah lingkungan akan menyebabkan hilangnya biomassa lamun (Syukur et al., 2017).

Para nelayan lokal dengan mudah menangkap sebagian besar ikan perangkap, nelayan menggunakan bahan beracun dari tuba. Teknik ini yang secara lokal disebut 'kamande' diyakini sangat efektif untuk mengarahkan rombongan ikan baronang ke dalam perangkap. Ikan dapat dihalau dengan bahan beracun tersebut dan bergerak menuju kolektor ikan di ujung perangkap.

Alasan di balik penurunan populasi ikan baronang adalah karena: (i) ada gangguan padang lamun sebagai lokasi pertumbuhan bibit \& lahan merumput dari ikan baronang; (ii) metode racun alami untuk menangkap ikan; dan (iii) penangkapan ikan dengan perangkap di lokasi agregasi bertelur. Selain itu, Burke etal. (2011) juga menyebutkan bahwa penyebab penurunan kualitas lingkungan perikanan adalah budaya perikanan yang merusak lingkungan yang didukung dengan penangkapan yang hanya mementingkan aspek ekonomi, penggunaan jangkar, sedimentasi dan perubahan iklim. 
Alternatif pertama adalah modifikasi sero sebagai alat utama penangkapan di area pemijahan. Modifikasi ini ini ukurannya harus dapat memberikan area luas untuk ruang pemijahan ikan tanpa mengalami stres. Konstruksi yang dirancang, dapat membuktikan bahwa nelayan tidak khawatir kehilangan ikan ketika air pasang datang. Ini harus dilakukan dengan cara berdiskusi

Biasanya mereka mengambil ikan pada malam hari (pada pukul 20.00-

21.00 WITA) ketika ikan masuk ke dalam perangkap. Penundaan panen sampai pagi hari memberikan waktu untuk telur berubah dari tahap V (telur matang) ke tahap hidrasi pada bulan September. Penundaan satu hari hanya memberi kesempatan ikan memijah secara alami 34,6\%. Penundaan pemanenan sampai 2 hari akan memberikan kesempatan pemijahan ikan sampai $90 \%$. Hal ini seharusnya cukup efektif untuk menjaga populasi benih yang akan menjamin keberlanjutan populasi sumberdaya ikan baronang di area tersebut.

Penangkapan dengan cara yang disebutkan di atas sudah dilakukan sejak lama. Dari hasil penelitian, ditemukan bahwa telah terjadi penurunan total tangkapan per tahun dari $190.600 \mathrm{~kg}$ pada tahun 1993 menjadi hanya 23.100 $\mathrm{kg}$ pada tahun 2003 , atau tersisa $12,1 \%$ dalam 10 tahun. Dapat diasumsikan bahwa penurunan populasi akan lebih besar seiring dengan waktu.

Area pemijahan dapat diwariskan dari generasi ke generasi seperti kepemilikan lahan, sehingga perangkap sero tambahan dapat dibangun. Jadi, dapat diasumsikan bahwa dengan menurunnya jumlah populasi induk, serta penambahan jumlah alat tangkap, akan semakin mempercepat habisnya sumberdaya ikan baronang di alam. Selanjutnya, di masa depan usaha penangkapan ikan baronang akan lebih sulit karena hasil tangkapannya menurun. Ekonomi masyarakat desa Papagaran tentu akan terpengaruh oleh kejadian ini. Pengenalan ikan asing ke perairan lokal dapat digunakan untuk meningkatkan jumlah tangkapan (Muchlisin, 2011).

Melihat data dan fakta yang ada, perlu direvisi kesepakatan warga desa. Memodifikasi jebakan sero dengan ruang pemijahan yang luas dan kuat. Nelayan harus melakukan penundaan untuk panen sampai pukul 10.00-11.00 WIB pada pagi hari berikutnya. Nelayan harus rela melepaskan beberapa indukan. Nelayan perlu belajar tentang metode menangkap lainnya untuk ikan beronang. Diseminasi hasil penelitian kepada penduduk desa Papagaran dan kepada warga lainnya.

Selain penurunan jumlah ikan sebagaimana dijelaskan di atas, terdapat pula faktor lain yang berkaitan. Berdasarkan penelitian (Kotelat, 2001), penurunan jenis ikan di perairan dapat disebabkan adanya pencemaran yang timbul akibat limbah rumah tangga dan dapat juga berasal dari pestisida yang digunakan untuk kepentingan pertanian. Di perairan sekitar pulau Papagaran yang ada adalah limbah rumah tangga dan limbah dari kegiatan transportasi laut. Selain itu racun tuba untuk penangkapan ikan tentu saja berpengaruh terhadap ekosistem laut. Penurunan ini pun dapat dipengaruhi oleh implementasi kebijakan dan/atau peraturan yang kurang relevan oleh karena tidak ditunjang oleh penelitian yang komperhensif. Tanpa menerapkan kebijakan pembatasan jumlah alat tangkap maka akan terjadi deplesi pada stok ikan (Purwaningsih, et al, 2012). Kebijakan dan sistem kelembagaan formal di bidang perikanan harus memperhitungkan aspek internalisasi kepada masyarakat (Yusufet $a l ., 2018)$. Selain faktor kebijakan 
penting untuk memperhitungkan keterpaduan aspek-aspek bio-technosocioeconomic dalam pengembangan pola pengelolaan perikanan (Nababanet al., 2007).

\section{SIMPULAN}

Penundaan menangkap hingga satu hari mempunyai peluang ikan baronang memijah $34,6 \%$ sedangkan penundaan 2 hari membuat lebih dari $90,0 \%$ ikan di dalam sero memijah secara alami dan telur yang dibuahi menetas pada hari berikutnya. Ada banyak potensi kehilangan ekonomi penduduk desa Papagaran dari penangkapan ikan baronang dalam 10 tahun.Ada dua penyebab penurunan populasi yaitu akibat menangkap massal dengan racun tuba, dan menangkap selama periode pemijahan di area pemijahan sekitar desa Papagaran.

Cara memperbaiki kondisi perikanan di Pulau Papagaran ini, rekomendasi kebijakan yang dapat diterapkan adalah dengan mengelola reservat sehingga keberlangsungan hidup ikan dan lingkungannya dapat terjamin dalam jangka panjang, pengaturan waktu tangkap agar ikan yang ditangkap adalah yang cukup umur, sudah memijah, dan mengganti metode tangkap menjadi metode yang lebih ramah lingkungan.

Rekomendasi kebijakan yang dapat diterapkan adalah dengan membuat reservat sehingga keberlangsungan hidup ikan dan lingkungannya dapat terjamin dalam jangka panjang, pengaturan waktu tangkap agar ikan yang ditangkap adalah yang cukup umur dan mengganti metode tangkap menjadi metode yang lebih ramah lingkungan. Hasil penelitian ini merekomendasikan perlunya strategi keberlanjutan populasi ikan baronang dengan cara menunda penangkapan 2 hari dari hari pertama bertelur. Kearifan local berupa peraturan desa harus direvisi, terutama di tempat pemijahan untuk memastikan terjaganya ikan.

\section{DAFTAR PUSTAKA}

BTNK, 2001. Peta Zonasi Taman Nasional Komodo (Berdasarkan Keputusan Direktur Jenderal Perlindungan Hutan dan Konservasi Alam No. 65/Kpts/D3-V/2001 tanggal 30 Mei 2001)

Budiarto Aris. (2015). Pengelolaan rajungan dengan pendekatan ekosistem di perairan Laut Jawa (WPPNRI 712). Tesis. Sekolah Pasca Sarjana - Institut Pertanian. Bogor.

Burke, B. L., Greenhalgh, S., Prager, D., $\&$ Cooper, E. (2008). Coastal Capital: Tobago The Economic Contribution of Tobago's Coral Reefs Coral. Coral Reefs, 66. Retrieved from http://www.wri.org/publication/coas tal-capital

Frisch, A. J. (2007). Growth and reproduction of the painted spiny lobster (Panulirus versicolor) on the Great Barrier Reef (Australia). Fisheries Research, 85(1-2), 61-67. http://doi.org/10.1016/j.fishres.2006 .12 .001

Harahap, A. P., Takemura, A., Nakamura, S., Rahman, S., \& Takano, K. (2001). Histological evidence of lunar-synchronized ovarian development and spawning in the spiny rabbitfish Siganus spinus (Linnaeus) around the Ryukyus. Fisheries Science, 67(5), 888-893.

http://doi.org/10.1046/j.14442906.2001.00337.x 
Hoque, M., Takemura, A., \& Takano, K. (1998). Annual Changes in Oocyte Development and Serum Vitellogenin Level in the Rabbitfish \&lt;i\&gt;Siganus canaliculatus\&lt;/i\&gt; (Park) in Okinawa, Southern Japan. Fisheries Science, 64(1), 4 5 http://doi.org/10.2331/fishsci.64.44

Hutomo, M., \& Martosewojo, S. (1977). The Fishes Of Seagrass Community On The West Side of Burung Island (Pari Islands, Seribu Islands) And Their Variations In Abundance. Mar. Res. Indonesia, 17(February), 147-172.

http://doi.org/10.14203/mri.v17i0.3 57

Jaikuma, M. (2012). A Review On Biology And Aquaculture Potential Of Rabbit Fish In Tamilnadu (Siganus canaliculatus). International Journal of Plant, Animal, and Environmental Sciences, 2(2), 57-64.

Jayanto, B. B., Boesono, H., Dian, A., Fitri, P., Studi, P., Sumberdaya, P., ... Diponegoro, U. (2016). Pengaruh Atraktor Cumi Terhadap Hasil Tangkapan Alat. Saintek Perikanan, 11(2), 134-139.

Kotelat, M. (2001). Freshwatter Fishese of Northern Vietnam.

Krishnamurthy, K., \& Jeyaseelan, M. J. P. (1981). The early life history of fishes from pichavaram mangrove ecosystem of india. Rapport et Proces-Verbaux Des Reunions Cons. Int. Explor. Mer, 178, 416423.

Muchlisin, Z. A. (2011). Analisis Kebijakan Introduksi Spesies Ikan Asing Di Perairan Umum Daratan
Provinsi Aceh. Kebijakan Sosial Ekonomi Kelautan Dan Perikanan, 1(1), 79-89.

Mustofa. (2010). Dana Bagi Hasil Dan Konservasi Sumber Daya Alam Di Indonesia Periode Desentralisasi. Jurnal Ekonomi \& Pendidikan, 8(2), 119-134.

Nababan, B. O., Dewita, Y., \& Hermawan, M. (2007). Analisis Keberlanjutan Perikanan Tangkap Skala Kecil di Kabupaten Tegal Jawa Tengah (Teknik Pendekatan RAPFISH). Jurnal Bijak Dan Riset Sosek, 2(2), 137-158.

Nurhayati, A. (2013). Analisis Potensi Lestari Perikanan Tangkap Di Kawasan Pangandaran. Jurnal Akuatika, 4(2), 195-209.

Park, Y. J., Takemura, A., \& Lee, Y. D. (2006). Lunar-synchronized reproductive activity in the pencilstreaked rabbitfish Siganus doliatus in the Chuuk Lagoon, Micronesia. Ichthyological Research, 53(2), 179-181. http://doi.org/10.1007/s10228-0050322-2

Pet J, et al, 2000. 25 Year Master Plan for Management 2000-2025 Komodo National Park Book 2. $\mathrm{p}: 64,74$

Prianto, E., Puspasari, R., Kartamihardja, E. S., \& Zulfia, N. (2014). Kajian kebijakan konservasi sumber daya ikan di Paparan Sunda. In Prosiding Seminar Nasional Ikan ke 8 (pp. 29-40).

Purwaningsih, R., Widjaja, S., \& Partiwi, S. G. (2012). Pengembangan Model Simulasi 
Kebijakan Pengelolaan Ikan Berkelanjutan. Jurnal Teknik Industri, $\quad \mathbf{1 4 ( 1 )}, \quad 25-34$. http://doi.org/10.9744/jti.14.1.25-34

Restu, I. W. (2011). Kondisi komunitas terumbu karang di pantai bias putih desa bugbug kecamatan karangasem kabupaten karangasem bali. Jurnal Bumi Lestari, 11(1), 58-65.

Saaty, T. L., \& Hu, G. (1998). Ranking by eigenvector versus other methods in the analytic hierarchy process. Applied Mathematics Letters, 11(4), 121-125.

http://doi.org/10.1016/S0893-

9659(98)00068-8

Sartini. (2004). Menggali Kearifan Lokal Nusantara Sebuah Kajian Filsafati. Jurnal Filsafat, 31(2), 111-120.

Sembiring, I., Wantasen, A. S., \& Ngangi, E. LA. (2012). Kajian Sosial Ekonomi Masyarakat Di Desa Tumbak Kabupaten Minahasa Tenggara. Jurnal Ilmiah Platax, I(September), 29-36.

Syukur, A., Wardiatno, Y., \& Muchsin, I (2017). Kerusakan Lamun ( Seagrass ) dan Rumusan Konservasinya di Tanjung Luar
Lombok Timur Program Studi Pendidikan Biologi Universitas Mataram Departemen Manajemen Sumberdaya Perairan , Fakultas Perikanan dan Ilmu Kelautan Institut Pertanian Bogor . J1 . Agatis. Jurnal Biologi Tropis, 17(2), 69-80.

Tamarol, J., Luasunaung, A., \& Budiman, J. (2012). Dampak Perikanan Tangkap terhadap Sumberdaya Ikan dan Habitatnya di Perairan Pantai Tabukan Tengah Kepulauan Sangihe. Jurnal Perikanan Dan Kelauatan Tropis, VIII(April), 12-16.

Tuegeh, S., Tilaar, F. F., \& Manu, G. D. (2012). Beberapa aspek biologi ikan Beronang (Siganus vermiculatus) di Perairan Arakan Kecamatan Tatapaan Kabupaten Minahasa Selatan. Jurnal Ilmiah Platax, I(1), 12-18.

Yusuf, D., Arief, A. A., Ali, S. A., \& Indar, M. Y. N. (2018). Analisis Peran Kelembagaan Lokal Nelayan dan Strategi Pengembangannya dalam Pengelolaan dan Pemanfaatan Telur Ikan Terbang di Kabupaten Polman Sulawesi Barat. Jurnal Akuatika Indonesia, 3(1). 